\title{
Conservation and Controversy in the Karakoram: Khunjerab National Park, Pakistan
}

\author{
Are Knudsen
}

\section{Introduction}

"The involvement of local people in planning and management of natural resources is now widely recognized as critical to conservation and development."

Guidelines for Mountain Protected Areas (D.Poore 1992:19)

High up in the Hunza valley a couple of thousand Wakhi people reside amidst some of Pakistan's most spectacular and rugged mountain scenery. They carve out a living from combining pastoral animal husbandry with some work migration and more recently, trekking tourism. Animals are moved across a vast mountain terrain, utilizing sub-alpine and alpine pastures in a complex pastoral herding system. During the summer, women take care of yaks, sheep and goats on the alpine pastures above 4,000 m. In late autumn, male herders move yaks to lower elevations where they look after them through the winter.

Whereas the resident Wakhi population has not been the source of great interest, conservation agencies have been alerted by the biodiversity importance of this area and its exceptional range of wild animals, some of them critically endangered. The area is home to the Himalayan brown bear (Ursos arctos), the world's largest snow-leopard (Panthera uncia) population, wild ungulates such as blue sheep (Pseudois nayaur), and Siberian ibex (Capra ibex siberica) and is the last refuge for the endangered Marco Polo sheep (Ovis ammon polii).

In 1974 the American wildlife biologist George Schaller proposed establishing a national park in the area (G.Schaller 1980:98ff.). The main objective of the park was to protect the Marco Polo sheep and, possibly, a remnant population of the rare Tibetan wild ass (Equus hemonius kiang). In order to comply with the World Conservation Union's (IUCN) guidelines for national parks, ${ }^{1}$ Schaller deliberately drew the borders so as to exclude permanent villages. The proposed park covering about 2,300 square km included all the major rangelands of the local Wakhi villagers, but this Schaller considered "details [which] could be resolved later" (ibid.:98). The then Prime Minister of Pakistan, Zulfiqar 
Ali Bhutto, enthusiastically embraced Schaller's proposal and on April 291975 the Kunjerab National Park (KNP) was formally declared ("gazetted") by the government (Figure 1).

My own involvement with the KNP controversy is based on two short periods of fieldwork in Shimshal, the Wakhi village which most adamantly rejected the national park plans (A.Knudsen 1992). Unannounced visits by foreign researchers, such as myself, aroused local suspicion and were associated with the park plans. Prior to my first visit in 1990 the Norwegian wildlife biologist Per Wegge had done a field survey in Shimshal (P.Wegge 1988). Since I was a Norwegian, villagers believed I was a wildlife specialist too. My research topic -- herd ownership, range management and agro-pastoralism -added weight to this interpretation. None of these topics were neutral. To the contrary, they were the type of information people in Shimshal jealously guarded and did not want to fall in the hands of national park "spies", of which many suspected, I was one.

Did the Shimshalis and the other Wakhi villagers have reason to be concerned? It is my contention that they did. Although details are lacking and the narrative is difficult to piece together, the following represents -- as far as I am able to ascertain -- the chain of events that hurled the Wakhi villages in the Khunjerab from relative obscurity in the 1970s to the center of controversy in the 1990s. My argument is that national parks, despite imposing heavy burdens on local people, are implemented primarily for the high conservationist profile this alternative offers. In particular, this paper is critical of the IUCN's preservationist approach to the Khunjerab National Park which studiously ignored the organization's own guidelines for mountain protected areas.

\section{The Khunjerab National Park ${ }^{2}$}

Due to the unresolved border dispute between India and Pakistan ("Kashmir conflict") the Northern Areas (NA) of Pakistan lack provincial status and are under federal administration from Islamabad. The region's lifeline is the Karakoram Highway (KKH), a $1,300 \mathrm{~km}$ artery which begins in Islamabad and ends at the Khunjerab Pass $(4,750 \mathrm{~m})$ where it crosses into China. The Khunjerab plateau is an old grazing ground for Wakhi villagers and in the Wakhi language Khunjerab means "Valley of Blood". Tourists who travel by bus across the plateau during summer can hardly imagine the hardships of living there, nor are they likely to see the rusty signboard which inform passers-by that they are entering the Khunjerab National Park.

1. National park (IUCN Category II): "To protect outstanding natural and scenic areas of national or international significance for scientific, educational, and recreational use. These are relatively large natural areas materially unaltered by human activity, where commercially extractive uses are not permitted" (IUCN 1985).

2. Parts of this section were discussed in an earlier publication (A.Knudsen 1995). 
Figure 1. Map of Karakoram and the KNP

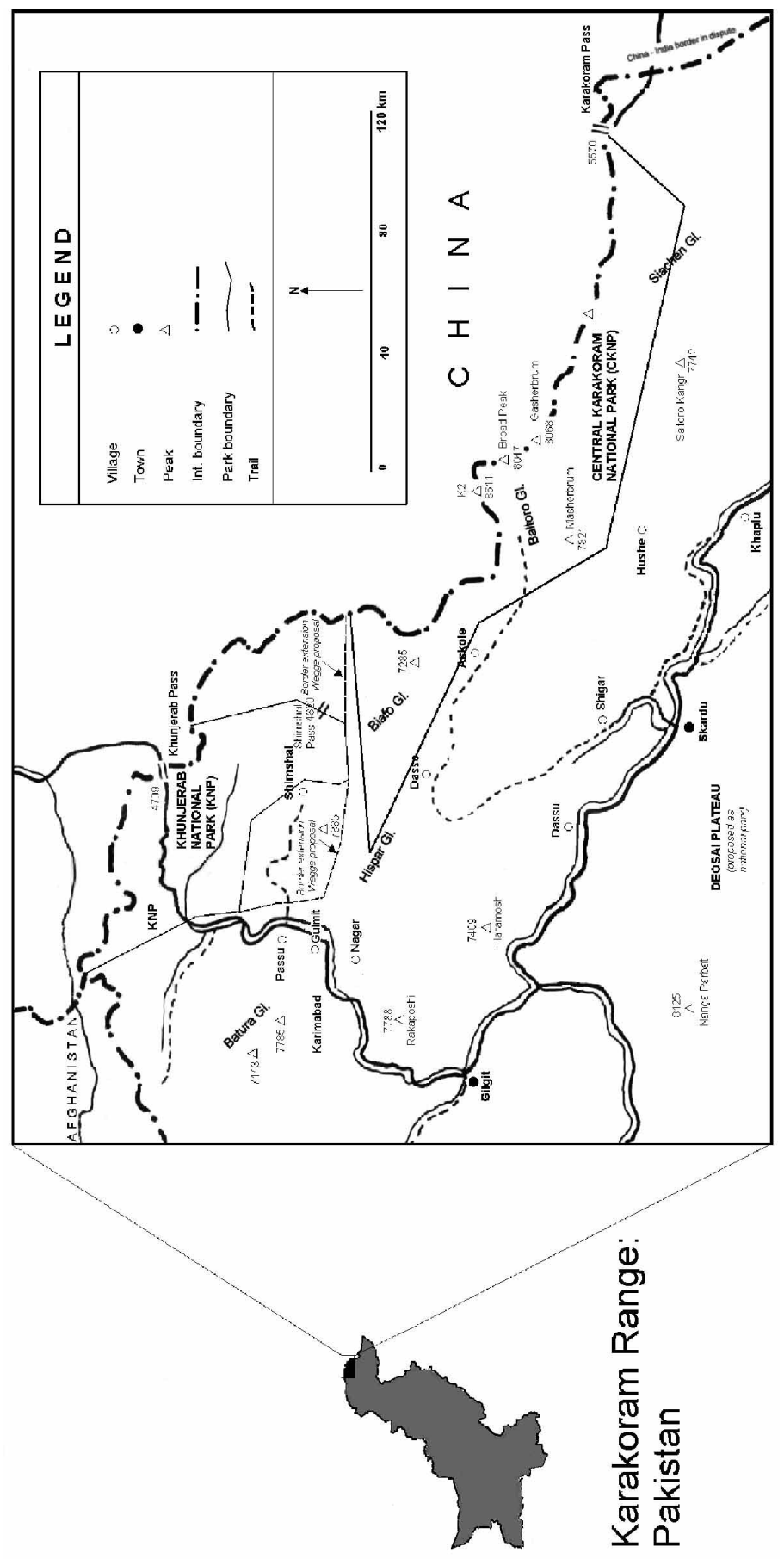


Until the late 1980s the park which was intended as a showcase of modern nature conservation, was little else than dotted lines on the map. There was only a rudimentary park staff and the lack of money and absence of a management plan meant that outside a small area close to the KKH, there was almost no supervision. The status of most of the wildlife was not known but the Marco Polo sheep -- the park's most threatened species -was declining at an alarming rate. Poaching had reduced the number of Marco Polo sheep from an estimated 300 in 1975 to about 100 in 1980. The last reliable confirmation was from 1992 when 52 Marco Polo sheep were spotted (WWF 1996:37). ${ }^{3}$ Local villagers, poachers, game wardens, army personnel and Chinese border patrols were all at one point singled out for blame, but no definite proof was ever produced.

Acknowledging the many shortcomings of the management of the KNP, especially the protection of the Marco Polo sheep, the government of Pakistan in collaboration with the IUCN set out to draft a new management plan. In order to assess the situation of wildlife in the park the IUCN asked Wegge to carry out a rapid appraisal and make suggestions for wildlife management. He conducted surveys and wildlife counts at different locations within the park (P.Wegge 1988) and completed the first expert wildlife study since Schaller in 1974. Based on his fieldwork Wegge argued that there was no scientific basis for the alleged competition between wildlife and domestic animals and therefore no need for a strictly defined "category II" national park. He also argued that the populations of ibex and blue sheep were large enough to sustain a commercial hunting program. The Marco Polo sheep, however, were critically endangered. In addition to immediate measures to save the Marco Polo sheep, Wegge proposed extending the park's borders and tripling its size from the original 2,300 square $\mathrm{km}$ to approximately 6,000 square $\mathrm{km}$ (Figure 1). His most controversial suggestion was abandoning the national park designation and turning the park into a Biosphere Reserve or Multipurpose Conservation Area (IUCN category VIII). This would make room for domestic grazing and allow the implementation of a commercial trophy-hunting program with profits accruing to the Wahki villagers. ${ }^{4}$

3. The Marco Polo sheep's core habitat is set aside as the "Kilik-Mintaka Game Reserve" (650 square $\mathrm{km}$ ) which is contiguous with the Chinese "Taxkorgan Nature Reserve". Marco Polo sheep, snow leopards and blue sheep are known to travel between the reserves.

4. Wegge (1992a: 112) estimated that annual fees from trophy hunting would amount to Rs. 300,000 (US\$ 12,500). All currency conversion uses the 1991 value of Pakistani rupees (ca. Rs. $24=$ US\$1). 
In the summer of 1989 the newly formed governmental organization, the National Council for Conservation of Wildlife (NCCW), convened a workshop in Gilgit to draft the framework of a new management plan for the KNP (B.Bell 1992). During the workshop, the Pakistani participants, as well as the invited foreign advisors, ignored Wegge's proposal and declared that their mandate was exclusively to draft a management plan for the original "category II" national park. One reason the participants did not support Wegge's proposal was that it would strain their relations with the government and downgrade the KNP from a national park to a Biosphere Reserve. This would involve changing the current legislation, and delaying the KNP management proposal (P.Wegge 1990, 1992b). ${ }^{5}$ The Conservator for Wildlife, Abdul Latif Rao, strongly opposed a revision of the KNP's status:

The [management] plan should be strictly in accordance with the purpose statement, objectives, and recommendations of the workshop which recognize the IUCN definition of a national park. Any attempt to deviate will frustrate the purpose (Rao, quoted in B.Bell 1992:131).

The minority among the participants asked the government to settle the compensation issue before proceeding with park planning (ibid.:137), but the majority recommended that all grazing should be stopped immediately (ibid.:22). Only if this strategy proved unsuccessful, should some grazing be allowed in selected areas until a phasing out program could be instituted. As an alternative for those affected, it was suggested that ecotourism and rural development schemes be promoted with the help of the Aga Khan Rural Support Program, a regional NGO. Apart from Wegge, only a few participants had previous knowledge of the area other than guided tours and excursions in preparation for the workshop.

\section{The aftermath of the Gilgit Workshop}

Details of the deliberations at the Gilgit Workshop were not known to the Wakhi villagers, but they soon caught wind of the fact that the new management plans would curtail their customary rights to graze their domestic animals and hunting of wildlife. Their concern over the new park plans and frustration over not being consulted quickly translated into ad hoc protests (S.Hussein 1994). Although the Gilgit workshop was not intended to draft a management plan but to prepare "a framework for a management plan" (B.Bell 1992:1), there was growing realization that more information was needed in order to achieve this goal. Seemingly unaware of the force of the local opposition, survey teams

5. The Northern Areas Wildlife Preservation Act of 1975. 
were dispatched to the Wakhi villages. In late 1989, Shimshal villagers twice refused to allow wildlife surveyors to conduct a reconnaissance (A.Ahmad 1991:14).

When the KNP was established in 1975 there were no attempts to restrict the grazing of domestic animals within the park. However, in the Khunjerab plateau about 12 square $\mathrm{km}$ of core habitat for the Marco Polo sheep had been designated a "no-grazing zone". Park guards occasionally patrolled the zone but the grazing ban was not strictly enforced and "illicit grazing continued in the area, with the silent consent of some of the park officials" (ibid.:13). Although the Wakhi villagers had not been denied access to other parts of the Khunjerab plateau, they feared that the new management plans would make further inroads into their customary use of the area.

In 1990 the seven Wakhi villages sharing grazing rights in the Khunjerab plateau filed a petition against the government to protest the new management plans (Civil Case File 1990). ${ }^{6}$ In this document the Wakhi villagers claim ownership of the Khunjerab plateau on the basis of customary use-rights. At the same time they refer to an oral agreement whereby they agreed to forego their use of the Khunjerab plateau for an annual compensation of Rs. 5,000 to each household. Because the government had not kept its promise of economic compensation, the Wakhi villages no longer felt bound by the agreement and would exercise their right to grazing in the area. In response to this claim, the Forest Department (which technically was in charge of the KNP's management) argued that following the notification of the KNP in 1975 the area became "crown land" and therefore they rejected the claim to monetary compensation.

The park's management was already at this point in disarray but there were more problems ahead. On October 151990 the Gilgit District Court announced its preliminary ruling which asked both parties to keep the status quo (Civil Case File 1990). Until a final agreement on compensation could be found, the court allowed the Wakhi communities to graze their animals in the Khunjerab, but not in the 12 square $\mathrm{km}$ no-grazing zone where domestic animals had been banned since 1975. Already prior to the preliminary court ruling, in August 1990, some Wakhi herdsmen had entered this zone with their animals.

To defuse the tension created by the confrontation with the Wakhi villagers, in mid1990 the World Wide Fund for Nature (WWF) commissioned additional field surveys in

6. Ghalapan, Morkhun, Jamalabad, Gircha, Sarthees, Nazimabad and Sust. To complicate the matter, some individuals from other villages enjoy grazing rights on the Khunjerab plateau. These rights were granted them by the former feudal ruler (Mir) of Hunza. Known as "Mir-shepherds" they have continued to contest for their grazing privileges. Although strongly opposed to the KNP, Shimshalis do not have grazing rights on the Khunjerab plateau. 
the affected villages. When the team members arrived in Pakistan in August 1990, they learned that the Wakhi villagers' resentment over the KNP had induced them to bring a case against the government. The survey was therefore abandoned but one of the team members, the American scholar John Mock, was able to complete his fieldwork (J.Mock 1990:1). Speaking fluent Urdu, Mock single-handedly surveyed all the affected Wakhi villages and concluded that the "decision to ban all human activity ... would seem to guarantee the failure of the park" (ibid.:3). The report had been commissioned by the WWF's headquarters in Geneva but neither WWF nor IUCN took note of Mock's critical remarks or of his suggestions for redressing local grievances. On May 261991 the Wakhi herdsmen in the Khunjerab no-grazing zone were forcibly evicted by the paramilitary "Khunjerab Security Force" (KSF). A checkpoint was erected at the border to prevent animals and herdsmen from drifting in again. The incident caused spontaneous demonstrations in which Wakhi villagers blocked the traffic on the KKH and shouted slogans criticising the government (T.Slavin 1991:51).

Prompted by the clash with the KSF in May 1991 the seven Wakhi villages sharing grazing rights in the Khunjerab plateau drafted an unsigned "position paper" which details the injustice inflicted upon them and their demands for monetary compensation (Table 1). The Rs. 5,000 per household laid out in the civil case against the state in 1990 had now grown to Rs. 182 million (US\$ 7,58 million), that is about Rs. 1 million (US\$ 47,619) in economic compensation to each of the about 180 affected households (Table 1). Additionally, the villagers claimed compensation for loss of grazing privileges amounting to Rs. 1,8 million annually. These figures may seem inflated and not a realistic estimate of the loss sustained by local villagers, but they covered not only compensation for loss of access to grazing grounds but also illegal logging and sale of timber during the construction of the KKH through the Hunza valley. A noteworthy exception in this paper is that there is no mention of the right to hunt. That the ban on hunting (except for the Marco Polo sheep) had not been strictly enforced, could be one explanation of why this is not mentioned. The paper is, however, explicit about the need for local people to be involved in the park's management.

In 1991 new initiatives were taken to break the deadlock and the government asked Ashiq Ahmad, a wildlife specialist, to contact the defiant villagers. In June of the same year, Ahmad met with representatives of the Wakhi villagers in order to draft an agreement between them and the government. In his consultancy report, Ahmad (A.Ahmad 1991:15) warned of the consequences of accepting the demands of Wakhi villagers (Table 1). If the demands for compensation were accepted, Ahmad argued, it would set a costly precedent for similar demands elsewhere. Instead, Ahmad advised the government to either endorse 
Wegge's initial plan for a zoning of the KNP or allow grazing throughout the park, thereby removing the grazing issue altogether (ibid.:18). Ahmad also favoured upholding the ban on wildlife hunting throughout the park.

\section{Table 1}

Demands for compensation by the villagers of Ghujal Tehsil, Hunza Subdivision (Gilgit District) for governmental interference in the Khunjerab National Park

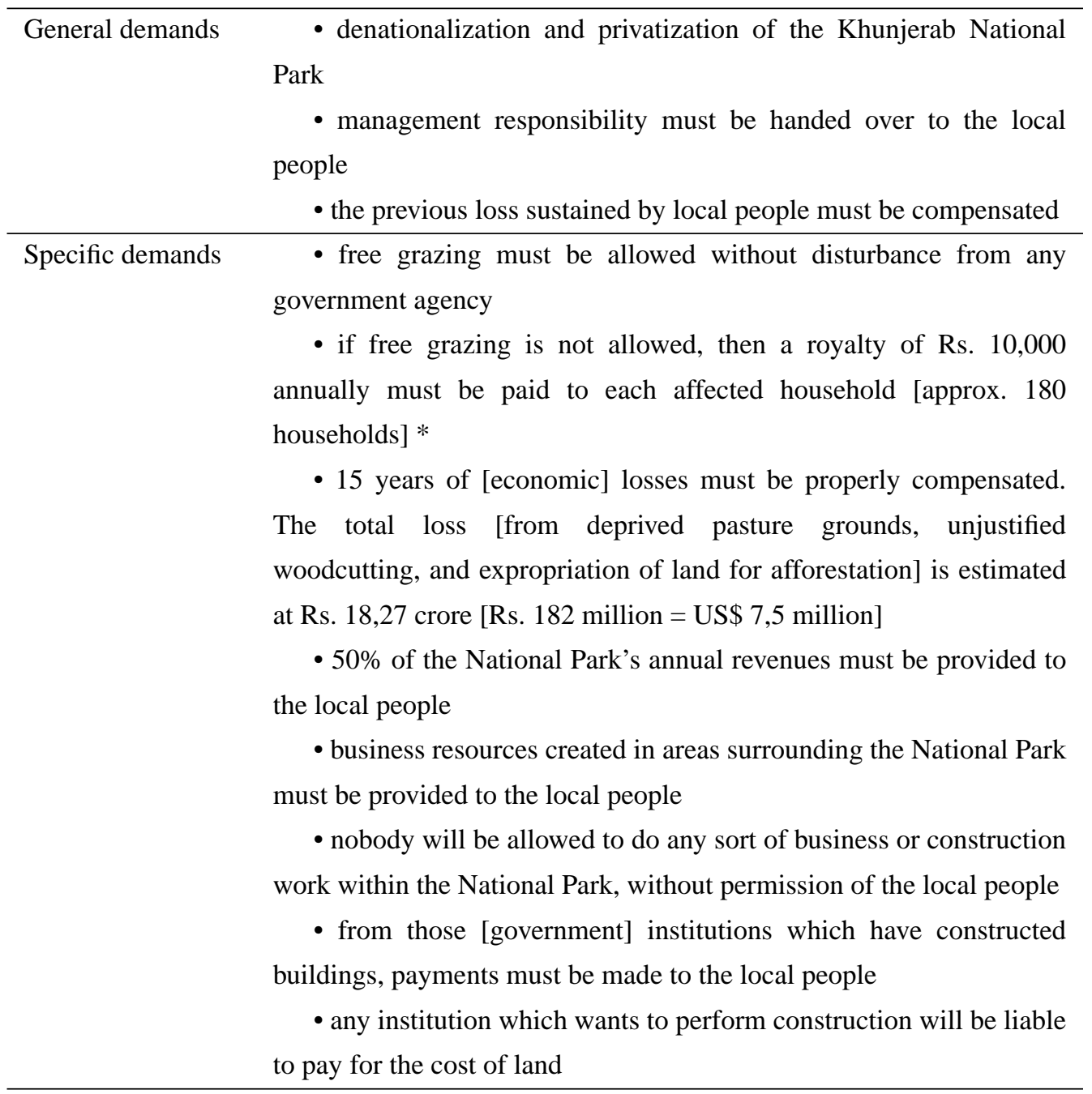

* The original text uses the term "individual" but the intent is likely to be "household".

Source: Reproduced (with some language editing) from H.Kreutzmann (1995:225) and the original source document (Anonymous 1991). 
Table 2

Excerpt of agreement between graziers of Khunjerab and the

Northern Areas Administration, 1992 ("Khunjerab Agreement")

Range management

Wildlife protection

Employment

Compensation

Trophy hunting

Management

Conditions
- provided that the number of animals comply with scientific

estimates of carrying capacity, traditional concessions of grazing

will be allowed to continue

- all hunting is banned. Enforcement of the ban entrusted with

Khunjerab Village Organizations

- $80 \%$ of employment opportunities to local communities

- guiding, portering, lodging of visitors provided by local communities

- resting periods when graziers and livestock will vacate the Khunjerab pastures, compensation (minimum) Rs. 1,000 per month

- $70 \%$ of revenues (minus management charges) from trophy hunting to local communities

- constitution of a Management Board (eight seats); the NA's administration (2), the park administration (1), Inspector General of Police (1), AKRSP (1), WWF (1) and representatives of graziers in Khunjerab (1) and Shimshal (1)

- the NAs adminstration will suspend the agreement (in part or whole) in case of violation of grazing and wildlife prescriptions

- a maximum of 100 yaks will be allowed in the "core zone"

The suggestions made in Ahmad's report were used as a basis for drawing up an agreement with Wakhi villagers in January 1992 (Table 2). Ahmad -- who in the meantime had become Director of Conservation for WWF-Pakistan -- was able to negotiate a deal between the seven Wakhi villages along the KKH and representatives of the Northern Areas Administration. Despite the huge discrepancy between the agreement and the demands for compensation set forth in the 1991 declaration (Table 1), the seven Wakhi 
communities signed the agreement. The only affected community which did not sign was Shimshal. Their main reason for not signing the agreement was that it bans hunting. This would put an end to the hunting of blue sheep and ibex, both important sources of venison during winter months. Moreover, it would outlaw the culling of wild predators, in particular wolves (Canis lupus), hunted with rifles and ancient stone traps.

Figure 2. Wolf killed in stone trap. Photo by Author.

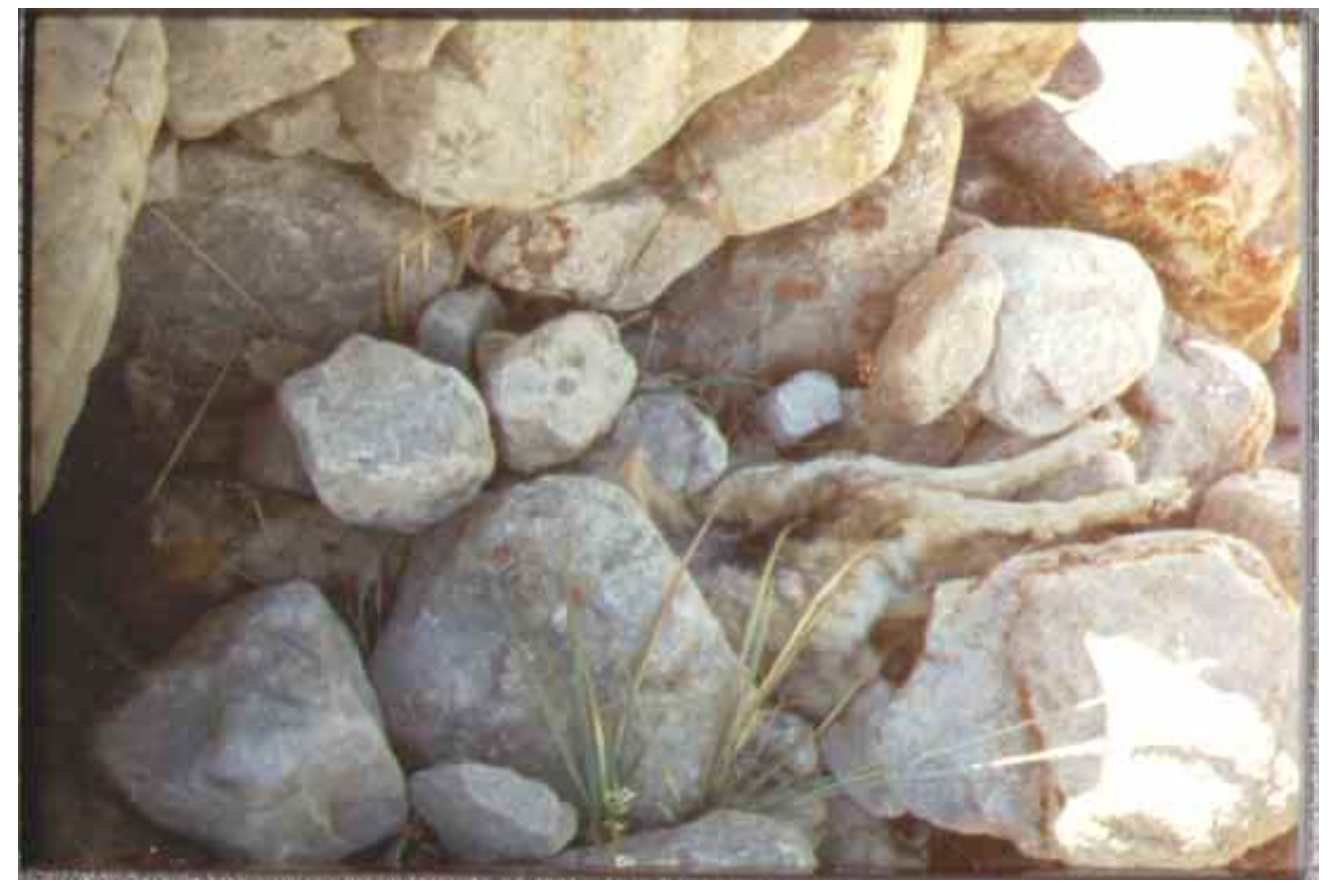

Despite the fact that the agreement relaxes the "no-grazing" clause and allows "traditional concessions of grazing" under certain conditions (Table 2), the Shimshalis remained sceptical of any interference with their customary herd management. They feared that this was only a first step towards ending the grazing of domestic animals inside the KNP. Unlike the seven Wakhi villages along the KKH, the Shimshalis did not graze animals on the Khunjerab plateau, nor were they willing to trade their customary grazing rights for monetary compensation. For them, economic compensation had never been an issue. It is, therefore, all the more surprising that the other Wakhi villages signed because the agreement does not refer to the compensation issue. One reason why the other Wakhi villagers signed could be the implied use of force. In order to make the Shimshal villagers sign the agreement, in 1991 the government dispatched the district Commissioner to the village. Arriving by helicopter he threatened to imprison the spokesman of the Shimshal 
villagers, the village headmaster Daulat Amin. Only through an eloquent defence, highlighting the predicament of the village, the importance of their pastoral economy and the villagers' history of loyalty to Pakistan, was the commissioner talked out of taking action against Amin. ${ }^{7}$

\section{Collaborative management of the KNP}

It is a common problem that "community-based tenurial rights are not recognized by nation states" (O.Lynch and J.Alcorn 1994:376). A general strategy for resolving this problem is "co-management" (F.Berkes 1991) or "collaborative management" (G.Borrini-Feyerabend 1996) which is currently being explored as a management tool in some national parks (K.Rao and C.Geisler 1991). The formation of a Management Board (Table 2) was a positive step towards the collaborative management of the KNP. However, there are a number of obstacles before this can become a reality. First, the agreement obliges the graziers to forego their right to hunt and to accept restrictions on grazing as well as sudden closures when that is deemed necessary. Secondly, the agreement specifies the size of local recruitment to the park's management but is unclear on whether they would have any real influence on the administration of the park. Thirdly, the affected Wakhi villages were promised seats in the proposed Management Board, but the board was to be chaired by the Administrator of the Northern Areas, the highest authority of the region. The agreement therefore suggests a definite power imbalance in favour of the government.

Shimshal is the only major village in Hunza without a link road to the KKH. The 60 $\mathrm{km}$ hike to the village takes two days, and is an exhausting venture through steep granite gorges and across shifting scree slopes, rivers and glaciers. Lacking a road, the village has been left outside the many development changes seen elsewhere in Hunza: there is neither electricity nor mechanized agricultural equipment in the village. To end their isolation villagers began constructing a road themselves in September 1985, aided by a loan from the Aga Khan Rural Support Program. When the money ran out, they hoped that the government would feel obliged to complete it. After some years of standstill, the government contracted the work to local entrepreneurs and road construction was resumed. The road is still not completed. Shimshalis long for an end to their isolation, but there is apprehension that construction of the road will give the local administration an alibi for greater intervention in community affairs and will be used to put pressure on the community to agree to the KNP plans. ${ }^{8}$

7. David Butz, pers.comm., February 1996. 
Shimshal is the only Wakhi community in upper Hunza ("Ghujal") to engage in extensive pastoral animal husbandry. No other community moves so many animals over such large distances. Shimshal's pasturelands spread out over more than 2,700 square km, extending from the KNP's western boundary and eastward towards the Chinese border (Figure 1). Inter-village grazing rights are common to Wakhi villages in Ghujal (e.g., the Khunjerab pastures), but the about 120 households in Shimshal have sole ownership of these pastures, ranging in altitude from 3,000 to 5,000 m. The mountain pastures are of vital importance for the mixed mountain agriculture found in Shimshal. The Shimshal valley $(2,700-3,200 \mathrm{~m})$ is an arid area and village agriculture is based on gravity fed irrigation of glacial melting water. Reflecting the Shimshal villagers' dependence on livestock, the number of yaks, goats and sheep per household are significantly higher than the district average (District Ghujal) (Table 3). For Shimshal, the KNP plans are therefore especially threatening and as one villager explained it: "If they make it a national park, Shimshal will be a tomb" (A.Knudsen 1992:102). Another quote underlines the perceived seriousness of the situation: "First they can kill us, then they can come and make it a national park" (Slavin 1991:49).

Table 3

Mean number of livestock per household 1985, 1995

\begin{tabular}{lllll} 
& \multicolumn{3}{c}{ Shimshal } & District Ghujal \\
& & & & \\
& 1985 & 1995 & 1985 & 1995 \\
Yak & 3,5 & 8 & 1,1 & NI \\
Cows & 2,1 & 3,3 & 4,1 & NI \\
Sheep \& goats & 61,6 & 58,5 & 25,5 & NI \\
& \\
Sources: AKRSP (1987), Kreutzmann (1986), Shimshal Natural Resources \\
Program (Online) NI = No information
\end{tabular}

8. David Butz, pers.comm., February 1996. 
FIGURE 3. Journey's end: Male yak being slaughtered in Shimshal. Photo by Author.

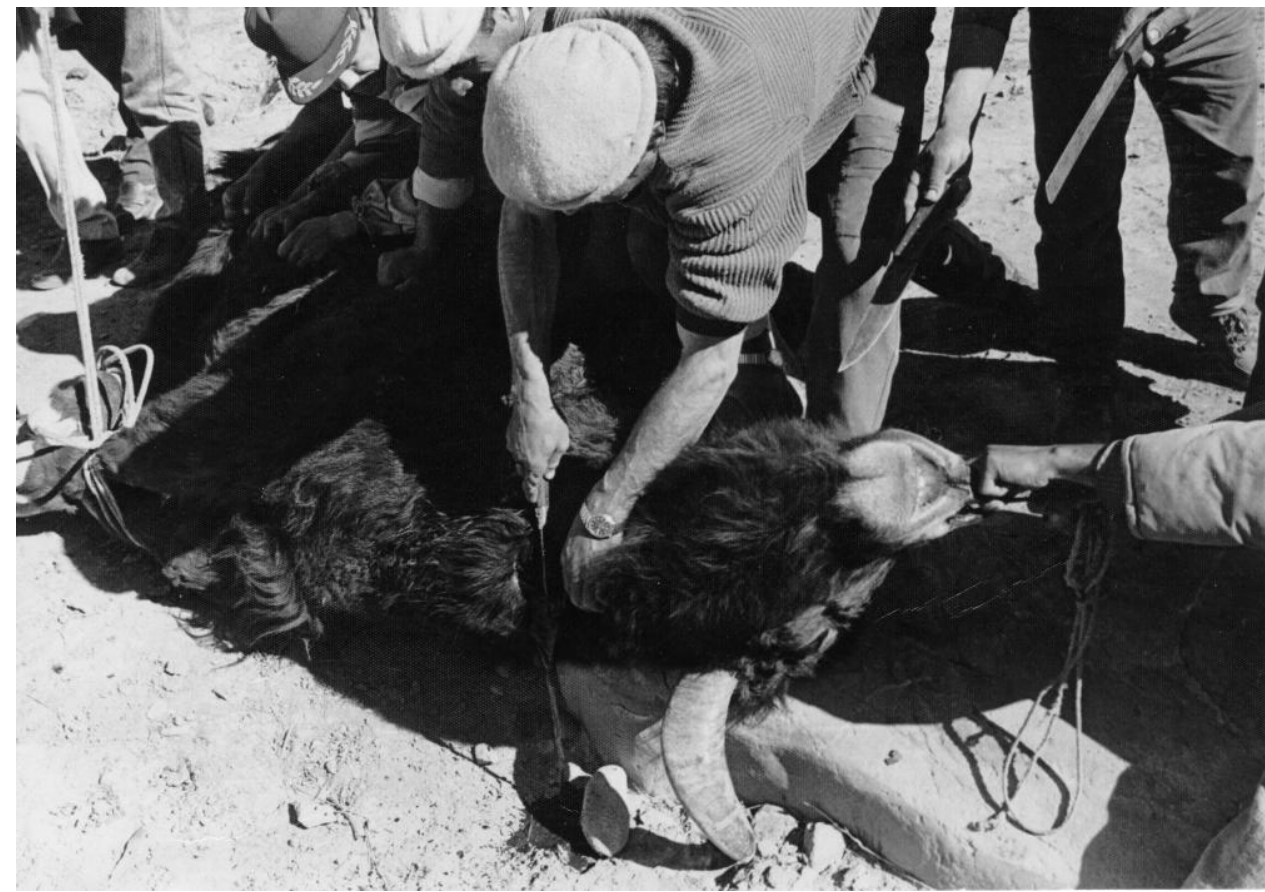

Instead of acknowledging the significance of this community, enforcement of the park plans would put an end to their pastoral animal husbandry. The plan to sedentarize the Shimshalis overlooked the cultural significance of their mountain pastures (pameer) and the biannual migration (kooch) to and from the pastures which are high points in Shimshalis' pastoral cycle (A.Knudsen 1992:46). The original park plans would fragment this local management system and upset pastoral migrations which were fully compatible with the aims of conservation. Already in 1979 the IUCN's guidelines for conservation in mountain environments pointed out that:

Especially in arid and semi-arid regions, nomadic grazing and transhumance often make the best sustained use of grazing lands; these traditional practices should not be changed without very good reason (R.Dasmann and D.Poore 1979:27).

The Shimhalis' herd management system would seem to be a typical example of a "traditional practice" and, as confirmed by range surveys, over-grazing was hardly evident (P.Wegge 1988). Brandon and Wells (1992:565) are correct that "there has been a 
tendency to 'glamorize' ... indigenous resource management practices" but it is dangerous to write them off before their potential role has been established. Moreover, while it is commonly assumed that domestic animals disturb, displace or compete with wildlife, domestic animals in the KNP have helped sustain the large carnivore population and relieved some of the predator pressure on wild ungulates (A.Ahmad 1991:10). ${ }^{9}$

The 1992 agreement was to mark the dawn of a new partnership between Wakhi villagers and the government but this did not happen, probably because both sides remained unconvinced of the others' intentions. In 1992 the proceedings from the Gilgit Workshop (B.Bell 1992) were published, sponsored by the US National Park Service, the Pakistani government and the IUCN. Interviews with Wakhi villagers are summarized on less than a single page (ibid.: 43), and demonstrate how little time and effort were spent consulting with the affected communities. However, there has since been increasing recognition that the KNP issue cannot be resolved unless the government adopts a more conciliatory stance vis-à-vis local communities. In September 1994 the WWF-Pakistan representative Chaudry Inayatullah admitted to many of the problems in the park. ${ }^{10} \mathrm{He}$ explained that during the period 1991-94 there had not been much progress in the planning process. Inayatullah stressed that the rules governing grazing in the park were too strict and should be relaxed. He was also critical of the current stationing of the Khunjerab Security Force (KSF) on the KNP border which increased local mistrust and opposition to the park. To improve relations with local people he suggested an immediate removal of KSF personnel and involving village organizations in park management. Instead of adopting Inayatullah's sound policy advice the WWF did not officially soften its stance on the KNP-issue and the WWF-sponsored booklet "An Ecotourist's Guide to the Khunjerab National Park" (WWF-Pakistan 1995) refers neither to the disputed nature of the park nor to the grievances of the Wakhi villagers.

\section{The new management plan}

The revised management plan for the KNP was presented during an inauguration ceremony in Gilgit in November 1996 (WWF 1996). The plan is to be commended for trying to solve the complex issues at stake, but falls short of providing new answers to how they can be resolved (Table 4). The total operating costs for activities planned under the five-year management plan amount to a staggering Rs. 57 million (ca. US\$ 1,5 million)

9. Researchers disagree over this point. Some argue that the size of wildlife populations has been exaggerated and that domestic animals do compete with wild ungulates (WWF 1996: 114, 119).

10. Presented at the Skardu Workshop, 28-29 September 1994. 
(WWF 1996:xvi) and underlines the problem of sustainability as "protected areas will not generate enough revenues to cover their costs" (J.Dixon and P.Sherman 1991:69). Park fees to be paid by visitors can be a significant source of income but studies from the Northern Areas show that both the number of visitors and the ability to collect park fees are very low. Cross-checking different sources, Mock and O'Neil found that about 2025,000 tourists per year visit the Northern Areas and Chitral (1996:10) but only a minority of these were trekking tourists. Revenues from park fees are negligible and in 1992 amounted to only Rs. 56,600 (US\$ 1,500) (Development Research Group 1995). ${ }^{11}$ To cover costs for compensating those giving up grazing as well as loss of domestic animals to predators the plan suggests levying an entry fee on all vehicles crossing the Khunjerab plateau (WWF 1996:64).

\section{Table 4}

Excerpts from the new KNP management plan, 1996

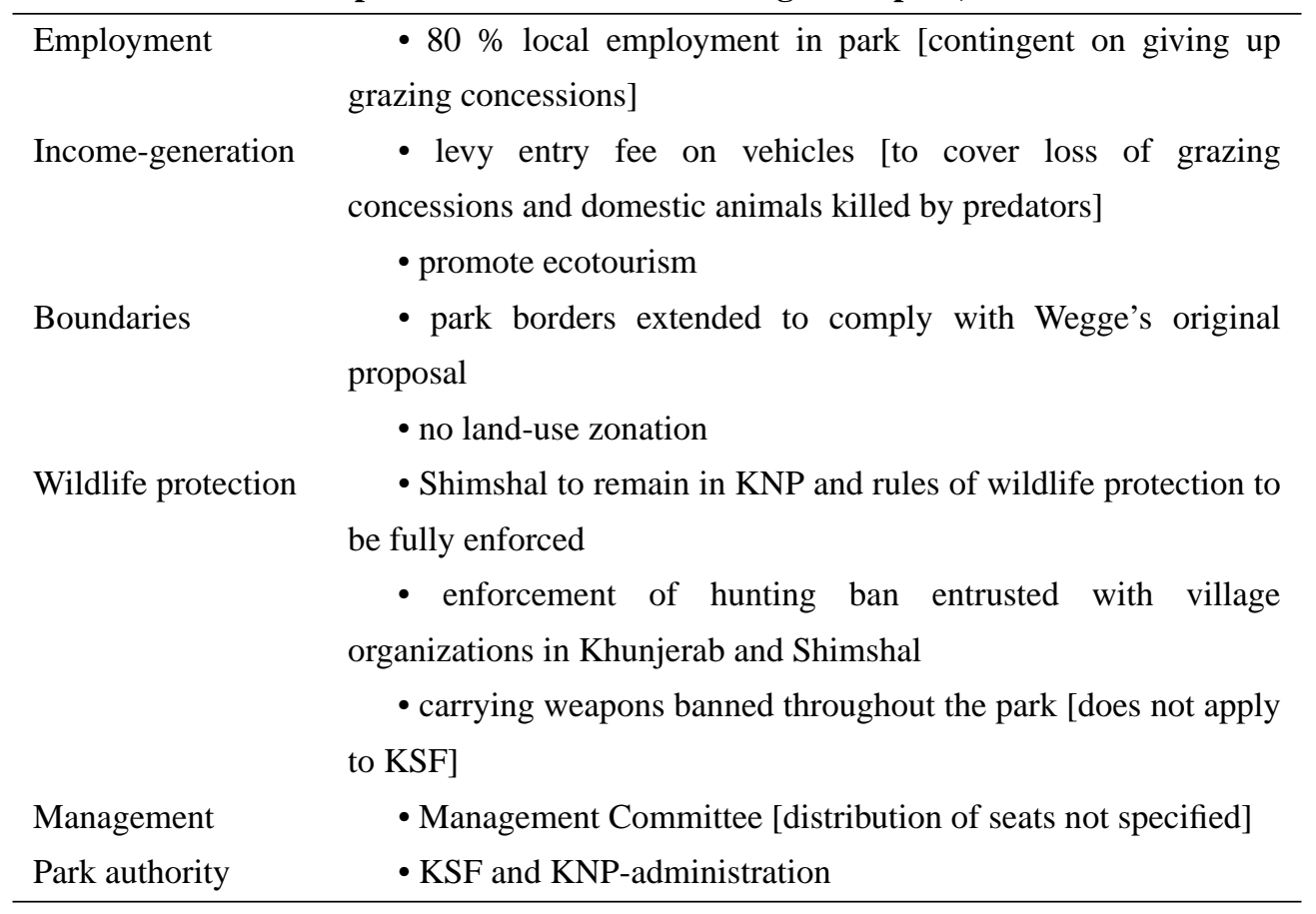

Source: WWF (1996)

11. In comparison, peak fees paid by climbing expeditions in 1992 totaled Rs. 3,7 million (US\$ 152,700) (Development Research Group 1995:58). 
This is a promising source of income but depends on factors such as the number of vehicles, the willingness-to-pay and a transparent and accountable system for dividing funds between park bodies and local communities. In accordance with Wegge's earlier plan the new management plan suggests enlarging the KNP to a total of 6,150 square $\mathrm{km}$ but does not, as suggested by Wegge, include land-use zoning as a management tool (Table 3). The reason given for not dividing the park into land-use zones (core, protected and hunting zones) is that not enough is known about wildlife habitats and doing so would require the closure of areas now used for domestic grazing (WWF 1996:38). Because hunting zones had not been identified, a commercial trophy hunting program (as planned under the "Khunjerab Agreement") could not be implemented (Table 2). Instead, the plan suggests immediate measures to protect wild ungulates (in particular Marco Polo sheep and Tibetan wild ass) and large predators. The plan promotes ecotourism as a new source of income, but mentions neither the compensation issue nor easing the ban on hunting. Despite vesting enforcement of the ban on hunting with village organizations, this is unacceptable to Shimshalis, who consider the culling of predators essential to the viability of their pastoral animal husbandry. ${ }^{12}$ The new park plan promises 80 per cent of KNP job opportunities to local communities (ibid.:47) but this offer is made contingent upon surrendering grazing concessions and is therefore not applicable to Shimshal. What remains is the possibility of promoting ecotourism, of which Shimshal is already the prime beneficiary (A.Knudsen 1992:69ff.).

In some respects the new management plan was "too little too late" and elements of the plan had already been pre-empted by the grassroots initiatives of Wakhi villagers. Aided by funding from senior Pakistan People's Party politicians -- most prominently former President Farooq Leghari -- the "Khunjerab Villagers Organization" (KVO) consisting of the villages along the $\mathrm{KKH}$, has initiated its own conservation program in a $30 \mathrm{~km}$ buffer zone outside the KNP's border (Z.Khan 1996). Similarly, Shimshal villagers have formed their own "Shimshal Nature Trust" which aims to protect the environment and preserve biodiversity. ${ }^{13}$ Neither of these initiatives has been welcomed by the authorities and there is local resentment that "the big environment NGOs which were on the scene when ..[we]..

12. Some have speculated that Shimshalis are hunting large predators to extinction in order to erode the foundation of the park (WWF 1996:116). No evidence has been produced to confirm this charge.

13. The management plan of the "Shimshal Nature Trust" is available on the internet (Online) as is the "Shimshal Natural Resources Program" (Online). As a corollary of this plan, Shimshalis have reduced their own hunting of ibex and blue sheep but are skeptical of allowing trophy hunting by foreigners (Inayatullah Ali, pers.comm., June 1999). 
were against conservation have jilted us after we took matters in our own hands" (ibid.:142). Villagers believe they should have a say in the management of the KNP and suspect that the plans will enrich the government at their expense. According to Qurban Mohammed, spokesman for the KVO, Wakhi villagers are:

"interested in developing the Khunjerab National Park, but the management of the park should be in local hands. The government will take the profit without involving the people. They just want to take all this beautiful land away and leave us empty-handed" (Q.Mohammed, quoted in T.Slavin 1991:49).

The lack of trust between Wakhi villagers and the government has so far made collaborative management of the KNP impossible. In order to protest the police checkpoint put up by the para-military Khunjerab Security Force (KSF) in 1991, the KVO erected its own "people's" (awami) checkpost just north of the one maintained by the KSF. ${ }^{14}$ The stationing of the KSF in the park increases Wakhi villagers feeling of being under siege. The KSF's principal mission is to guard national security interests at the Chinese border but it is also the de facto authority of the KNP. Park regulations ban carrying weapons inside the KNP but this does not apply to the KSF. ${ }^{15}$ Being both better organized and armed enables the KSF to "exercise more control over park resources than KNP staff ... Consequently, park rules and administration are relegated to a secondary position" (WWF 1996:44-45). The plan suggests vesting formal park authority with the KNP administration but there is in reality no short-term administrative solution to the problem.

\section{The Central Karakoram National Park}

The government of Pakistan had hoped that the KNP would become Pakistan's first park to be recognized as a "World Heritage Site", a prestigious list of the world's outstanding natural and cultural sites under UNESCO's World Heritage Convention. The unresolved problems in the KNP made the authorities realize that they would need to look elsewhere to fulfil this ambition. Both India and Nepal have national parks listed as a World Heritage Sites but Pakistan has none. ${ }^{16}$ The Pakistani government has been eager

14. Hermann Kreutzmann, pers.comm., September 1996.

15. The KSF has been accused of hunting "the endangered species [in the KNP] with the very weapons with which they are supposed to protect them" (Development Research Group 1995:81).

16. Nanda Devi National Park, Kaziranga National Park, Keoladeo National Park, Sunderbans National Park (India); Sagarmatha National Park and Royal Chitwan National Park (Nepal). 
to end this regional imbalance and in 1992 asked the IUCN to initiate the groundwork for a new national park in the vicinity of K2 $(8,611 \mathrm{~m})$, the world's second highest mountain. In the mid-1970s George Schaller had concluded that a national park around K2 was unnecessary, suggesting instead that the government should pursue what later became the KNP. In 1992, however, a survey by the IUCN's senior advisor Jim Thorsell (1992:4) concluded that the natural values of the Central Karakoram area "are clearly exceptional on a world scale" and would meet the criteria of a World Heritage Site. The initial park proposal for the "Central Karakoram National Park" (CKNP) covered about 3,000 square $\mathrm{km}$ and included the major mountain massifs, watersheds and glaciers of the central Karakoram region (Figure 1). ${ }^{17}$

In September 1994 the government was ready to follow up Thorsell's recommendations and for that purpose organized a workshop in Skardu, the main town in Baltistan. Unlike the Gilgit Workshop in 1989, affected communities were invited to participate and had been consulted during field visits prior to the workshop. In addition to village representatives from Baltistan, a representative of the Khunjerab Villagers Organization was invited to the workshop. The token inclusion of local villagers generally, and a representative of the defiant Wakhi villagers especially, signalled a new attitude on the part of the government and a redirecting of IUCN-Pakistan's conservation strategy for mountain protected areas (S.Fuller 1994). The initial park proposal from the Ministry (Ministry of Food, Agriculture and Livestock 1994) planned to include three villages (Hushe, Khaplu and Askole) comprising about 1,200 persons within the park's boundaries while the remaining 29 villages, totaling about 13,300 persons, would be included in the "buffer zone". During the workshop a more detailed map of the park was prepared, and following the wish of local representatives from Hushe and Askole, the park's southern border was moved slightly northwards thereby shifting them into the planned buffer zone. Otherwise, zoning as a management tool was neither discussed at the workshop, nor later included in the park proposal from the Pakistani authorities.

The representatives from Hushe and Askole stressed the importance of proper consultation and engaging in a dialogue with local communities (S.Mallick 1994). They were also concerned about proper compensation for losses of domestic animals to wild predators and respect for existing land-use practices. Another concern was the pressure tourism and trekking put on the scarce forest vegetation. In the Hushe valley the number of trekking tourists had doubled during the period 1989-92 to an estimated 16,000 man-days

17. The Siachen glacier was later excluded by the Ministry of Defence due to the continued engagement between Pakistani and Indian forces in the region. 
per season (J.Thorsell 1992:6). In addition, firewood was carried out of Hushe to cater for trekking parties along the Baltoro glacier. For the people of Hushe it was important that the park could help them raise living standards and improve health conditions, especially reducing the high infant mortality.

Taken together the KNP, CKNP and the Deosai plateau (proposed as a national park) would form a contiguous conservation area -- often referred to as a "bio-region" (J.McNeely 1992b:141) -- covering about 50 per cent of the central Karakoram ecosystem. Whereas local people were consulted, there were no concrete discussions of how the CKNP should be managed, nor was co-management discussed as a management option. The park plans involved imposing a hunting ban throughout the park but the implications for animal husbandry were not discussed. The workshop was not short of expert advice on the people and the region but only a few of the invited researchers had been solicited for advice. However, in order to gain a better basis for evaluating the potential for trekking tourism, the IUCN later commissioned a study of ecotourism in the Northern Areas under its Biodiversity Project (J.Mock and K.O’Neil 1996). Pakistan is currently seeking a "World Heritage Site" nomination for the CKNP. There are a obstacles to this nomination, especially the extensive armed forces deployment in the area and the dispute over jurisdiction between Pakistan and India (the "Kashmir conflict").

\section{Changing perceptions of national parks}

There is a growing realization that national parks, as traditionally conceived, are illfitted to the reality in developing countries (K.Ghimire and M.Pimbert 1997; D.King and W.Stewart 1996:297). This, in particular, concerns the question of residence in national parks. Here, the views are sharply divided, varying from those who advocate peoples' rights to traditional livelihoods (K.Ghimire and M.Pimbert 1997), to those who are critical of allowing human residence in national parks (K.Brandon et al. 1998). The latter "conservationist approach" is linked to what is termed the "Yellowstone model" which emphasized that national parks should preserve the pristine beauty of the wilderness, hence, resident people were perceived as an obstacle to the aims of conservation (E.Kemf 1993:6). Despite recent attempts to reconcile the needs of conservation with human rights through more selective approaches (P.Dearden et al. 1996), the denial of the customary use rights of native populations remains the single most problematic issue in national parks in the developing world (M.Colchester 1994). A world-wide survey of national parks found that almost "two-thirds of the parks reported illegal removal of wildlife, and half reported removal of vegetation, poor relations with local people, and conflicting demands for park resources" (J.McNeely 1990:18). Criticism of national parks has also been made on 
pragmatic grounds, arguing that most are too small to have tangible effects on conservation or foster an insular mentality where the park itself is carefully managed, while surrounding areas are left open for exploitation (ibid.:20). The critique of national parks has also focused on social injustice (B.Orlove and S.Brush 1996) and the costs inflicted on resident populations (M.Pimbert and B.Gujja 1997). While the direct costs of establishing and running a national park are borne by the state (or foreign donors) the indirect costs from, for example, increased predator pressure are borne by the local communities. Local people also stand to lose opportunity costs, that is the costs incurred through lack of access to grazing, hunting, etc. as a result of the park (M.Wells 1992). In general, the direct costs are rather small since governments typically allocate a minimum of funds for running parks. The main costs are therefore those which are inflicted on local people through the creation of the parks. This problem is especially acute in those cases where establishing national parks results in eviction or displacement of the original inhabitants (K.Rao and C.Geisler 1991). An alternative to national parks is a participatory approach such as "Integrated Conservation-Development Projects" (ICDPs) (K.Brandon and M.Wells 1992). ICDPs seek to promote conservation by providing alternative income for the inhabitants but are not, as sometimes claimed, a development panacea (M.Wells 1992:240). A central feature of ICDPs is land-use zoning and the creation of buffer zones. While land-use zoning was previously seen as a way to accommodate the need of different user groups with wildlife protection, recent studies are less optimistic that the zoning principle can achieve multiple-use in national parks (M.Colchester 1994:31). In particular, "it may be difficult to convince local people that restricted buffer-zone access is a valuable benefit if (a) they had unrestricted use of the area before establishment of the protected area; or (b) many of the resources of the proposed buffer-zone area had already been degraded or depleted -- both common situations on park boundaries" (M.Wells 1992:240).

In order for people to value conservation they must be secured income from resources which supported them in the past and be allowed to earn supplemental income. Currently, ecotourism is advocated as the most promising avenue for creating alternative employment for resident populations. A general problem with ecotourism is that most of the profits are not realized locally, but pocketed by national and international tour operators (K.Brandon and M.Wells 1992:36; M.Colchester 1994:33). The amount of money earned locally tends to be low and locals are left with the negative impacts of modern ecotourism, which, despite its appealing name, is not always "environment friendly". A major problem in the high mountains of Northern Pakistan is the firewood requirements of foreign expeditions and trekking tourists which put heavy pressure on the 
sparse forest cover. Another problem is campsite-specific impacts such as garbage dumps and human waste (S.Rashid 1994).

In the late 1980s, a new conservation "paradigm" emerged which stressed the need for nature conservation to become more profitable as well as better accounting for the loss of biodiversity. This "pragmatic" approach to nature conservation led to the foundation of community-based trophy-hunting programs, giving economic benefit to local communities. Despite increasing criticism of such programs in East and Southern Africa (C.Gibson and S.Marks 1995), trophy-hunting has been promoted as the only viable strategy for wildlife management in Pakistan because "a complete ban on hunting, which in theory sounds fantastic, is severely counter-productive in reality. It is logistically impossible for the government to enforce it" (Durrani, quoted in S.Mallick 1994). This approach has gradually gained acceptance and both IUCN and WWF now run communitybased trophy-hunting programs in the Northern Areas (A.Nasar 1995; Z.Khan 1996). ${ }^{18}$

The willingness of the IUCN and WWF to initiate participatory conservation projects is in stark opposition to the confrontational stance adopted in the KNP. A possible reason for the strict preservationist approach to the KNP is institutional inertia on the part of the IUCN. At the time of the workshop in Gilgit, land-use zoning was already common and used to good effect in some of Nepal's protected areas (P.Wegge 1992b:59). Moreover, the IUCN's Chief Conservator Officer, Jeffrey McNeely, had already begun advocating more pragmatic conservation measures. In 1988, a year prior to the Gilgit Workshop, McNeely published "Economics and Biological Diversity" (J.McNeely 1988). In this book and subsequent articles he outlined the organization's new approach to nature conservation and wildlife management (J.McNeely 1989, 1990). Central themes were the active use of economic incentives (and disincentives) in order to conserve biological resources. The IUCN now placed greater importance on preserving natural and cultural diversity (J.McNeely 1992a) and acknowledged that "relationships between people and land have too often been ignored or even destroyed by well-intentioned but insensitive resource conservation and management initiatives" (J.McNeely 1992b:140). Against this background, it is puzzling that the IUCN so strongly endorsed the category II designation for the KNP. During the Gilgit Workshop in 1989 John B. Sale (sitting in for Martin Holdgate, Director General of IUCN) declared that:

IUCN and similar international conservation organizations stand ready to assist in the development and implementation of the management program [in the KNP],

18. Recent examples of such programs can be found in the IUCN Progress Report (IUCN 1999) and the ibex conservation plan for Hushey Village Organization (HVO 1997). 
assuming that it continues to follow the internationally recognized norms for a national park. It is clear from this workshop that the Government of Pakistan has this firm intention. Nothing should be allowed to deflect from this admirable resolve (Sale, quoted in B.Bell 1992:133).

Despite the changes which had taken place in the IUCN's conservation policy the organization endorsed the category II designation and made this mandatory for continued support of the park planning process. Moreover, the IUCN ignored advice from Wegge, the organization's own consultant and the most knowledgeable person on the status of wildlife in the KNP.

FIGURE 4. A vanishing sight? Yaks cross the Pameer pastures. Photo by author.

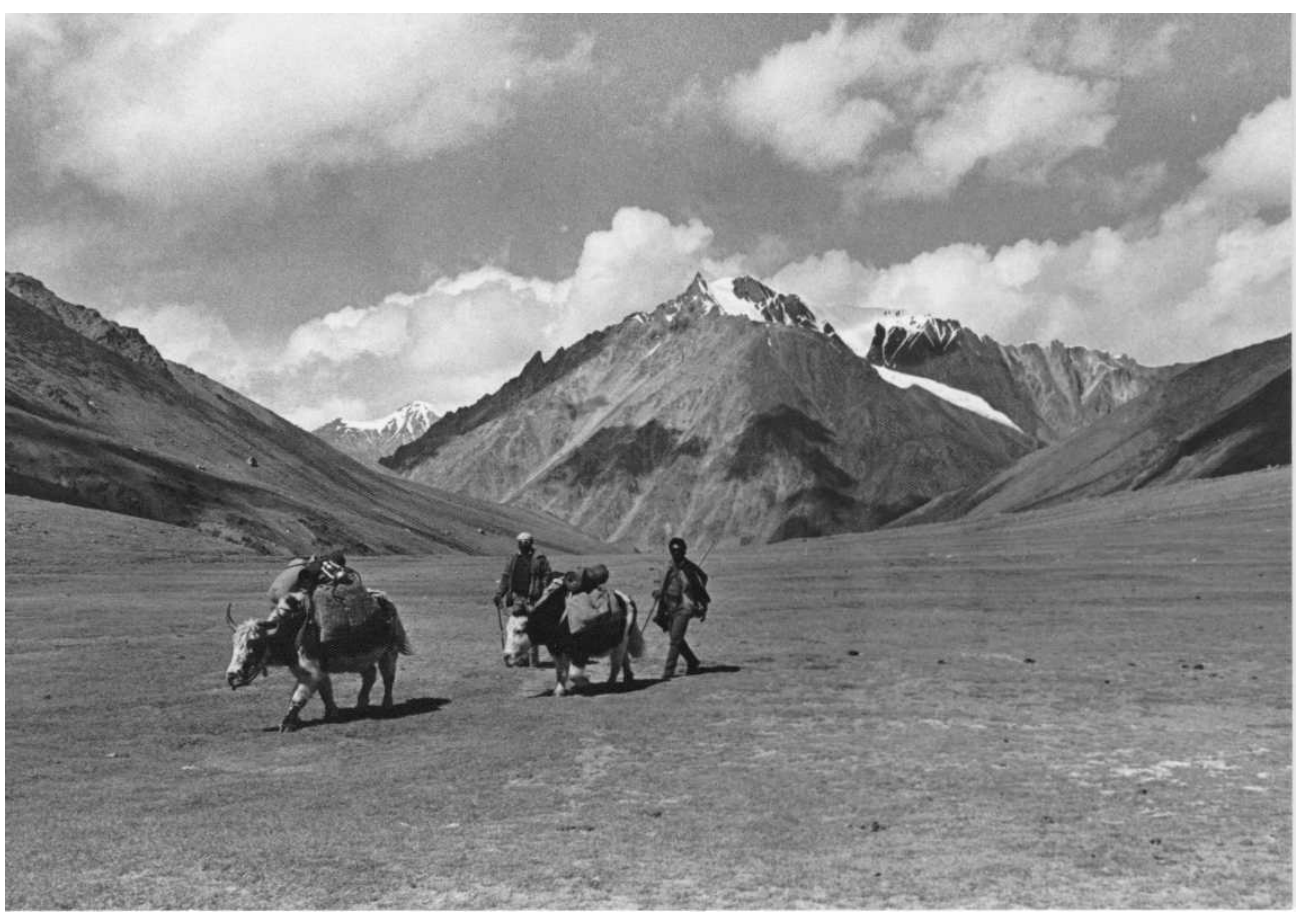

\section{Conclusion}

An integral part of Pakistan's nature conservation policy has been the creation of national parks. ${ }^{19}$ There has been neither an exhaustive evaluation of this policy, nor indepth studies of the current status of wildlife in Pakistan's national parks, game reserves 
and wildlife sanctuaries. The available information suggests that national parks in Pakistan neither attract foreign tourists nor provide adequate protection of wildlife. The inability to protect the critically endangered Marco Polo sheep is a case in point. Conservation efforts have also failed due to inadequate research, faulty advice and lingering stereotypes, especially the belief that mountain dwellers are purposely destroying their environment.

The KNP was planned as "a showcase of effective conservation in developing countries" (B.Bell 1992:135) but became an embarrassing failure. In particular, the planning exercise was a lesson in how not to gain popular support for a park. The park became a battle-ground between conservationist objectives and an increasingly vocal opposition. The original park plans violated the customary use-rights of the affected Wakhi villagers, and for Shimshal especially, undermined their livelihood and threatened their future. The Pakistani authorities have put a lot of energy into addressing the problems in the KNP, but have still not resolved the issues which are most troublesome, in particular restrictions on hunting and grazing. It is important to note that the Wakhi villagers -despite their small number and limited means -- have staged a successful grassroots campaign and have frustrated attempts to make them comply with the strict rules governing the park. We do not know, however, what these acts of civil disobedience have cost Wakhi communities in terms of lost income, distress and internal disruption. The costs to the government have also be considerable, leading them to declare that they "had no desire to repeat this experience, and ... adopted a participatory model for its recent initiative for a Central Karakoram National Park" (SPCS 1996:164). The planning process for the CKNP confirms that the government is seeking to avoid past mistakes. However, whereas local villagers were under certain conditions supportive of the park plans, the Pakistani authorities have neither decided how to tackle demands for economic compensation nor accommodated existing land-use practices within the guidelines of a category II national park.

In the KNP, the government implemented an outdated conservation model (the "Yellowstone model"), despite the fact that it been replaced by more sensitive conservation measures. Moreover, the IUCN actively supported this strategy long after it was clear that it was doomed to failure. This criticism also applies to the governmental wildlife agency, the NCCW, which was adamant that the only management option for the KNP was the category II designation. At the same time, this case study illustrates some of

19. According to a country report prepared for FAO (R.Anwar 1996) the government of Pakistan in collaboration with the IUCN plan to increase the number of national parks from the present 14 to a total of 35 . 
the difficulties of integrating traditional range management practices into park management.

By taking an historical perspective this case demonstrates the practical limitations of co-management. Pakistani conservation efforts have been least effective in gaining approval from those who are most affected. There has been a definite arrogance in the government attitude towards local people and an unwillingness to involve them in park planning and management (K.MacDonald 1995). This is not the Pakistan government's fault alone, as part of the blame must fall on the parent organizations of the IUCN and WWF, whose global mission for protecting wildlife has failed to address the needs of local people who, mostly against their will, become involved in wildlife conservation. This case study also exposes the high costs of management, including collaborative management, and the problems of protecting the environment under a tight federal budget. Economic considerations compel Third World governments to follow the IUCN's strict guidelines for national parks. Still, the application of the "exclusionary principle" is neither the IUCN's invention nor a novelty on the South Asian continent: as long ago as in 1910 the powerful Marahajah of Kashmir had expelled residents from his private deer reserve (R.Tucker 1991:44). The management problems in the Khunjerab National Park can be traced to the tradition of denying the rights of local people. If the government of Pakistan, the IUCN and WWF can find ways to address the grievances of the Wakhi villagers, they stand a good chance of creating a bio-region of global importance with the potential to preserve Northern Pakistan's natural and cultural heritage.

\section{Acknowledgements}

I am indebted to Nigel J. R. Allan, David Butz, Hermann Kreutzmann, Ken MacDonald, John Mock and Per Wegge for sharing information and unpublished material on the Khunjerab National Park. I am grateful to Eyolf Jul-Larsen, Johan Helland and anonymous JPE reviewers for helpful comments and Arne Kalland for organizing the workshop where this paper was first presented. A publication grant from the Chr. Michelsen Institute enabled me to rewrite a previous draft and Richard Moorsom to proofread my English. The responsibility for the present argument remains with the author. 


\section{References}

Ahmad, Ashiq.

1991. "The Feasibility and Application of Different Management Options to Resolve the Problems of Khunjerab National Park (Northern Areas)". Peshawar: Pakistan Forest Institute.

Anonymous. 1991.

"Some of the facts and realities about the inherited pasture: Khunjerab Pass and how it was named a national park" (mimeo).

Anwar, Rashid. 1996.

"Country Report for Pakistan: National Conservation Activities, Chapter 3". FAO Country Reports (Available http://web.icppgr.fao.org/oldsite/CR/CR/PAKI/c3.htm. Accessed March 31, 2000).

AKRSP. 1987.

Pastures and livestock development in Gojal. Agha Khan Rural Support Programme, Report No. 5 (Author: S. Mehjabeen Abidi).

Bell, Barbara Goodman, Ed. 1992.

International Workshop on the Management Planning of Khunjerab National Park June 7-16, 1989 (Proceedings), Gilgit, Northern Areas: United States National Park Service, The Government of Pakistan, National Council for Conservation of Wildlife and The World Conservation Union.

Berkes, Fikret. 1991.

"Co-management: The evolution in theory and practice of joint administration of living resources". Alternatives, 18(2):12-18.

Borrini-Feyerabend, Grazia. 1996.

Collaborative Management of Protected Areas: Tailoring the Approach to the Context. Gland: IUCN - The World Conservation Union.

Brandon, Katrina Eadie and Michael Wells. 1992.

"Planning for people and parks: Design dilemmas". World Development, 20(4):557-570

Brandon, Katrina E., Kent H. Redford and Steven E. Sanderson, Eds. 1998.

Parks in Peril: People, Politics, and Protected Areas. Washington D.C.: Island Press.

Civil Case File. 1990.

“'Suit for Declaration and Consequential Relief'. In the Court of Civil Judge 1st Class No. 1, Gilgit. Announced October 15, 1990, File No. 6". Gilgit.

Colchester, Marcus. 1994.

"Salvaging nature: Indigenous peoples, protected areas and biodiversity conservation". Geneva: United Nations Research Institute for Social Development.

Dasmann, Raymond F. and Duncan Poore. 1979.

Ecological Guidelines for Balanced Land Use, Conservation and Development in High Mountains. Gland: UNEP, IUCN and WWF.

Dearden, Philip, S. Chettamart, D. Emphandu and N. Tanakanjanaet. 1996.

"National parks and hill tribes in Northern Thailand: A case study of Doi Inthanon". Society and Natural Resources, 9(2):125-141.

Development Research Group. 1995.

"Mountain Tourism in the North West Frontier Province and the Northern Areas of Pakistan: An Overview". Kathmandu: ICIMOD (Mountain Enterprises and Infrastructure) 
Dixon, John A. and Paul B. Sherman. 1991.

"Economics of protected areas". Ambio, 20(2): 68-74.

Fuller, Stephan. 1994.

"High hopes in Karakoram". The Way Ahead - Pakistan's Environment and Development Quarterly, 1(3):3-10.

Ghimire, Krishna B. and Michel P. Pimbert, Eds. 1997.

Social Change and Conservation: Environmental Politics and Impacts of National Parks and Protected Areas. London: Earthscan and UNRISD.

Gibson, Clark C. and Stuart A. Marks. 1995.

"Transforming rural hunters into conservationists: An assessment of community-based wildlife management programs in Africa". World Development, 23(6):941-957.

Hushey Village Organization (HVO). 1997.

Ibex Conservation Plan: Hushey Valley (Ghanche District). Islamabad: IUCN, Government of Pakistan and UNDP.

Hussein, Saneeya. 1994.

"Qurban Muhammed: The voice of seven villages". The Way Ahead - Pakistan's Environment and Development Quarterly, 1(3):5.

IUCN. 1985.

United Nations List of National Parks and Protected Areas. Gland: IUCN International Union for Conservation of Nature and Natural Resources.

IUCN. 1999.

Maintaining Biodiversity in Pakistan with Rural Community Development. Annual Progress Report, January-December 1998. Islamabad: IUCN.

Kemf, Elizabeth. 1993.

"In search of a home: People living in or near protected areas". In: E. Kemf, Ed. The Law of the Mother: Protecting Indigenous Peoples in Protected Areas. San Francisco: Sierra Club Books, pp. 3-11.

Khan, Zaigham. 1996.

"Call of the wild". Herald, 27(9, September):138-142.

Khunjerab Agreement. 1992.

"Text of the agreement between the graziers of Khunjerab and the local administration (Dated: 5th January 1992)", mimeo.

King, David A. and William P. Stewart. 1996.

"Ecotourism and commodification: Protecting people and places". Biodiversity and Conservation, 5(3):293-305.

Knudsen, Are J. 1992.

"Household viability and adaptability in a North Pakistan mountain village in transition". MA thesis, Department of Social Anthropology. Bergen: University of Bergen.

Knudsen, Are J. 1995.

"State intervention and community protest: Nature conservation in Hunza, North Pakistan". In: Ole Bruun and Arne Kalland, Eds. Asian Perceptions of Nature: A Critical Approach. Richmond: Curzon Press, pp. 103-125.

Kreutzmann, Hermann. 1986.

A note on yak-keeping in Hunza, Northern Areas of Pakistan. Production pastorale et société, 19(Autumn):99-106. 
Kreutzmann, Hermann. 1995.

"Globalization, spatial integration, and sustainable development in Northern Pakistan”. Mountain Research and Development, 15(3):213-227.

Lynch, Owen J. and Janis B. Alcorn. 1994.

"Tenurial rights and community-based conservation". In: D. Western and R. M. Wright, Eds. Natural Connections: Perspectives on Community-Based Conservation. Washington, D.C.: Island Press, pp. 373-392.

MacDonald, Kenneth I. 1995.

"A critique of the Karakoram Workshop with recommendations for improvement". In: S. Fuller and M. Gemin, Eds. Proceedings of the Karakoram Workshop, Skardu, Pakistan, September 28-29, 1994. Karachi: IUCN - The World Conservation Union, pp. 29-33.

Mallick, Seeme. 1994.

"Mohammed Aslam: Pinpointing key issues". The Way Ahead - Pakistan's Environment and Development Quarterly, 1(3):3-10.

Mallick, Seeme. 1994.

"Shakil Durrani: Trophy hunting". The Way Ahead - Pakistan's Environment and Development Quarterly, 1(3):9.

McNeely, Jeffrey A. 1988.

Economics and Biological Diversity: Developing and Using Economic Incentives to Conserve Biological Resources. Gland: International Union for Conservation of Nature and Natural Resources (IUCN).

McNeely, Jeffrey A. 1989.

"How to pay for conserving biological diversity". Ambio, 18(6):308-313.

McNeely, Jeffrey A. 1990.

"The future of national parks". Environment, 32(1):16-41.

McNeely, Jeffrey A. 1992a.

"Nature and culture: Conservation needs them both". Nature and Resources, 28(3):37-43.

McNeely, Jeffrey A. 1992b.

"IUCN new programme for parks and protected areas". Environmental Policy and Law, 22(3):138-143.

Ministry of Food Agriculture \& Livestock and Northern Areas Adminstration 1994.

The Central Karakoram Park: A Nomination Proposal for World Heritage List. Karakoram Workshop, 28-29 September 1994, Skardu, Northern Areas.

Mock, John. 1990.

"Field trip report and discussion paper on conservation and management of the Khunjerab National Park". Consultancy report to World Wide Fund for Nature.

Mock, John and Kimberley O'Neil. 1996.

Survey of Ecotourism Potential in the Biodiversity Project Area: Consultancy report to IUCN-Pakistan (Available http://www.monitor.net/ jmko/karakoram/biodivtc.htm. Accessed March 31, 2000).

Nasar, Anita D. 1995.

"The conservation conundrum". The Way Ahead - Pakistan's Environment and Development Quarterly, 2(3):31-34.

Orlove, Benjamin S. and Stephen B. Brush. 1996.

"Anthropology and the conservation of biodiversity". Annual Review of Anthropology, 25:329-352. 
Pimbert, Michel P. and Biksham Gujja. 1997.

"Village voices challenging wetland management policies: Experiencies in participatory rural appraisal from India and Pakistan". Nature and Resources, 33(1):34-42.

Poore, Duncan, Ed. 1992.

Guidelines for Mountain Protected Areas (Commission on National Parks and Protected Areas, CNPPA). IUCN Protected Area Programme Series No. 2. Gland: IUCN - The World Conservation Union.

Rao, Kishore and Charles Geisler. 1991.

"The social consequences of protected areas development for resident populations". Society and Natural Resources, 3:19-32.

Rashid, Salman. 1994.

"A reprieve for Rupal: The Green Earth Organization in action". The Way Ahead Pakistan's Environment and Development Quarterly, 1(3):27-29.

Schaller, George B. 1980.

Stones of Silence: Journeys in the Himalaya. New York: Viking Press.

Shimshal Nature Trust. Online.

Fifteen Year Vision and Management Plan. (Available http://www.brocku.ca/ geography/people/dbutz/shimshal.html. Accessed March 31, 2000).

Shimshal Natural Resources Program. Online.

Shimshal Natural Resources Program - 2nd Annual Report, 1995. (Available http:// www.monitor.net/ jmko/karakoram/snrp-tc.htm. Accessed March 31, 2000).

Slavin, Terry. 1991.

"Survival in a vertical desert". Tomorrow, 1(2):43-53.

Thorsell, Jim M. 1992.

"Towards a World Heritage Site in the Central Karakorum, Baltistan". Gland: IUCN The World Conservation Union, mimeo.

Tucker, Richard P. 1991.

"Resident people and wildlife reserves in India: The prehistory of a strategy". In: P. C. West and S. R. Brechin, Eds. Resident Peoples and National Parks: Social Dilemmas and Strategies in International Conservation. Tucson, AZ: University of Arizona Press, pp. 44-50.

Wegge, Per. 1988.

"Assessment of Khunjerab National Park and Environs, Pakistan". Ås: Agricultural University of Norway, Report to IUCN - The World Conservation Union.

Wegge, Per. 1990.

"A Khunjerab workshop gone awry". Himal, Sept/Oct:33-34.

Wegge, Per. 1992a.

"Khunjerab National Park: Ecological status and management recommendations". In: B. G. Bell, Ed. International Workshop on the Management Planning of Khunjerab National Park June 7-16, 1989 (Proceedings). Gilgit, Northern Areas: United States National Park Service, The Government of Pakistan, National Council for Conservation of Wildlife and The World Conservation Union, pp. 95-122.

Wegge, Per. 1992b.

"Khunjerab National Park in Pakistan: Socio-political constraints to proper conservation management". In: P. Wegge, Ed. Mammal Conservation in Developing Countries: A New Approach (Proceedings of a Workshop held at the 5th Theriological Congress in Rome, Italy, August 1989). Ås: NORAGRIC, pp. 57-63. 
Wells, Michael. 1992.

"Biodiversity conservation, affluence and poverty: Mismatched costs and benefits and efforts to remedy them". Ambio, 21(3):237-243.

WWF. 1996.

Management Plan: Khunjerab National Park. Lahore: World Wide Fund for Nature Pakistan.

WWF-Pakistan. 1995.

An Ecotourist's Guide to the Khunjerab National Park. Lahore: World Wide Fund for Nature Pakistan.

\begin{abstract}
This paper discusses recent conservation efforts in Northern Pakistan and the relevance of national parks as legal instruments in nature and wildlife conservation. Employing an extensive case-study approach the paper analyzes the problems afflicting the Khunjerab National Park and discusses why the World Conservation Union (IUCN) disregarded its own policy guidelines for mountain protected areas. The paper advocates a more democratic and pragmatic approach to nature conservation and argues that national parks as traditionally conceived impose heavy burdens on local people. Despite increasing criticism of national parks, they continue to be implemented often for no other reason than the high conservationist profile this alternative offers.
\end{abstract}

Keywords: Pakistan, national parks, wildlife conservation, Khunjerab National Park, local populations, Karakoram.

\title{
Resumé
}

Ce document met en exergue les efforts récents de conservation au nord du Pakistan et l'importance des parks nationaux comme instruments légaux pour la preservation de la nature. En se basant sur une approche qui s'appuie sur un cas d'étude, l'auteur analyse les problèmes auxquels le Park National de Khunjerab est confronté et explique les raisons pour lesquelles l'Union Mondiale pour la Conservation a ignoré ses propres orientations politiques pour la protection des zones montagneuses. L'auteur suggère une approche plus democratique et pragmatique pour la conservation de la nature et défend l'argument selon lequel la conception tradionnelle des parks nationaux constitue une grande pesanteur sur les populations locales. En dépit des critiques croissantes des parks nationaux, ceux-ci continuent à être implementés sans autre raison que celle de mettre en evidence le profil élevé de cetter démarche conservationiste.

Mots clefs: Pakistan, parks nationaux, preservation de la nature, Park National de Khunjerab, populations locales, Karakoram. 


\section{Resumen}

Este artículo discute los esfurerzos más recientes de conservación en el Norte de Pakistan, y la aplicabilidad de parques nacionales como instrumentos de conservación de fauna y de la naturaleza. Usando un metódo vasto de estudio de casos, esta obra analiza los problemas que el parque nacional de Khunjerab esta enfrentando y habla de porqué el World Conservation Union (la unión de conservación mundial) ignoró sus propias normas y guías para la protección de áreas montañosas. El artículo aboga por una meta más democrática y pragmática para la conservación de la naturaleza, y discute como el concepto tradicional de los parques nacionales impone cargos pesados en la gente local. Aunque hay una creciente crítica de los parques nacionales, ellos continuan siendo implementados en muchas ocasiones por no otra razón más de ser la única alternativa que ofrece de mostrar un perfil politico de ser conservacionista.

Palabres claves: Pakistan, parques nacionales, conservación de fauna y de la naturaleza, el parque nacional de Khunjerab, la gente local, Karakoram. 